\title{
Influence of Internal Audit and Internal Control System on Quality of the Financial Statement
}

\author{
Ngali Sumito ${ }^{1,}$ Hari Setiyawati ${ }^{2}$ Ratna Mappanyukki ${ }^{3 *}$
}

\author{
1,2,3 Universitas Mercu Buana \\ *Corresponding author. Email: r.mappanyuki@mercubuana.ac.id
}

\begin{abstract}
The expected results of this study are to obtain empirical evidence of the causes of financial report quality through the implementation of internal audits that are moderated by the effectiveness of the internal control system. The benefit of this research is to contribute scientifically to the science of public sector auditing and solve problems for governments throughout the ministry in improving the quality of financial reports through the implementation of internal audits and internal control systems. The process through surveys and grounded based on existing theories was developed into a model designed to examine the quality of financial reports obtained from the internal control system and the implementation of internal audits. The results of this study state that the Internal Audit Implementation does not affect the Quality of Financial Statements, if the Effectiveness of the Internal Control System as a result of the moderating variable does not affect the Quality of Financial Statements.
\end{abstract}

Keywords: Internal Audit, Effectiveness of Internal Control Systems, Quality of Financial Statement

\section{INTRODUCTION}

The related phenomenon in this study is the case found by the Supreme Audit Agency (BPK) that occurred in June 2016 "The Supreme Audit Agency (BPK) gave a modified opinion on the 2015 Central Government Financial Report (LKPP). Modified opinion was given because of some material misstatements. in the form of non-compliance with government accounting standards, weaknesses in the internal control system, non-compliance with statutory provisions. The application of Government Accounting Standards (PP) No. 71 of 2010 came into effect in 2015 has not run optimally due to several obstacles including: quantity of human resources in charge of managing finance, competence and commitment of regional heads in encouraging optimization of the application of accrual-based financial statements in the regions. The realization of transparency through the effectiveness of the internal control system, namely the control environment, risk assessment, control activities, information and communication and monitoring and realization of accountability is the implementation of internal audits through planning, communication and approval, availability of resources, policies and procedures and reporting of state financial management must fulfill the principles on time and be compiled by following generally accepted government accounting standards that will provide quality financial reports supported by evidence that is relevant, reliable comparable and understandable. In addition, this study aims to enrich the research which is using data from several different types of organizations so as to provide varied results [1].

\section{LITERATURE REVIEW}

\subsection{Internal Audit}

Internal audit (Internal audit) is an examination carried out by the company's internal audit section, the company's financial statements and accounting records as well as compliance with predetermined management policies and compliance with government regulations and provisions of applicable professional ties [2]. Government regulations such as taxation regulations, capital markets, environment, banking, industry, investment, and others. Internal audit is an assurance and consultation activity carried out independently and objectively designed to provide added value and improve the operations of the organization [3]. Internal audit helps organizations achieve their goals through a systematic and regular approach to evaluating and improving the effectiveness of risk management, control and governance. Internal audits must be carried out effectively and can provide added value to organizations and stakeholders. Internal audit activities are carried out as follows: 1) 
Planning, 2) Communication and Approval, 3) Resource Management, 4) Policies and Procedures, 5) Coordination, 6) Reporting to Management and Board Leaders [4].

Internal audit is the entire process of activities audit, review, evaluation, monitoring, and activities other supervision of the implementation of duties and organizational functions in order to provide adequate confidence that the activity has been implemented in accordance with the benchmarks that have been effectively and efficiently established for leadership interests in realizing governance good governance. so that a good internal audit will guarantee the implementation of activities in accordance with the provisions, one of which is the reliability of financial reporting.

\subsection{Internal Control System}

Internal Oversight is the entire process of audit activities, review, evaluation, monitoring, and other supervisory activities on the organization of duties and functions of the organization in order to provide adequate confidence in the activities carried out in accordance with the established benchmarks effectively and efficient for the benefit of leaders in realizing good governance [5].

Internal Control System is a process integral to the actions and activities carried out continuously by the leadership and all employees to provide adequate confidence for the achievement of organizational goals through activities effective and efficient reporting reliability finance, securing state assets, and compliance with the laws and regulations. So, if the internal control system is implemented with one of the objectives of the organization, namely the reliability of financial reporting will be achieved.

Government internal supervision apparatus is a). The Financial and Development Supervisory Agency, which is responsible to the President. b). The Inspectorate General functionally carries out internal supervision that is responsible to the minister / head of the institution. c) The Provincial Inspectorate is responsible to the governor. d). The Regency / City Inspectorate is responsible to the regent / mayor. The internal control system component consists of a control environment, risk assessment, control activities, information and communication and monitoring [6]. The descriptions of each component of the internal control system are as follows: 1) Control environment is integrity and ethical values, commitment to competence, board participation, commissioner or audit committee, management philosophy and operating style, organizational structure and policy and practice of human resources, 2) Risk assessment of financial statements is an action taken by management to identify and analyze risks that are relevant to the preparation of financial statements in accordance with Generally Accepted Accounting Principles (GAAP), 3) Control Activities (control activities) are divided into adequate segregation of duties, appropriate authorization of transactions and activities, adequate documents and records, physical control of assets and records and performance checks independently, 4) The purpose of an entity's accounting information and communication system is to start, record, process, and wipe organize transactions carried out by the entity and maintain accountability of related assets, 5) Monitoring activities related to ongoing internal control by management to determine that controls are operating, and have been modified in accordance with changing conditions.

\subsection{Financial Statement Quality}

Financial statements are structured presentations of the financial position of an entity that shows the results of management accountability for the use of resources owned [7]. The quality of financial statements is normative measures that need to be realized in accounting information so that it can fulfill its purpose as a joint need for users of government financial statements [8]. Indicators that include important elements in the quality characteristics of financial statements are: (a) Level of relevance (relevant), (b) Level of reliability (reliable), (c) Level of comparability (comparable), (d) Level of understanding (can be understood).

\subsection{Framework}

Internal supervision is the entire process of audit activities, review, evaluation, monitoring, and other supervisory activities for organizing tasks and organizational functions in providing confidence that activities have been carried out in accordance with the measures set effectively and efficiently for the benefit of the leadership in realizing good governance [5]. The relationship between the role of internal audit and the quality of financial statements is stated in the 2017 State Financial Examination Standard which states that the examiner can use the results of the APIP work, experts and / or examiners outside the BPK. Internal audit has a positive and significant effect on financial quality [1]. The role of internal auditors had a positive and significant effect towards financial reporting quality [9]. The mindset of the impact of Internal Audit, Internal Control System and Quality of Financial Reports can be seen in the picture as follows:

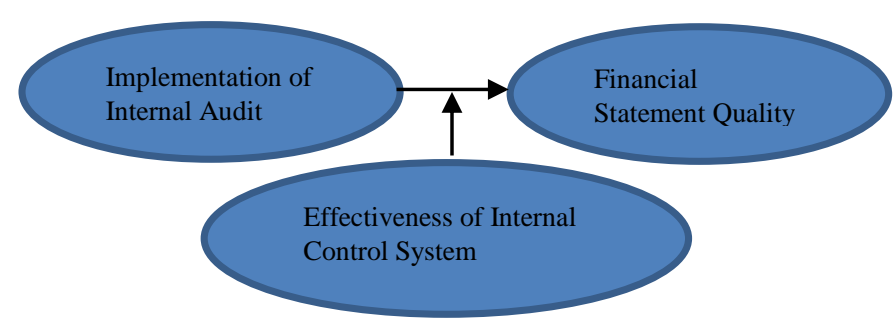

Figure 1 Framework

\subsection{Hypothesis}

Based on the framework that was stated earlier, the research hypothesis can be arranged as follows:

H1: The implementation of internal audit has a significant effect on the quality of financial statements.

$\mathrm{H} 2$ : The effectiveness of the internal control system moderates the significant influence of the implementation of internal audits on the quality of financial statements. 


\section{METHODS}

This research is explanatory research (explanatory research), namely research that explains causal relationships between variables through testing hypotheses. In this study, the effect of internal audit on the quality of financial statements will be tested to be moderated by the effectiveness of the internal control system. Ministry of Maritime Affairs and Fisheries (MMAF) is one of the Ministries and Institutions that received a disclaimer opinion from BPK-RI in 2016 and 2017. The target population in this study was all Work Units in the MMAF which amounted to 411. Samples were determined based on purposive sampling method with criteria: a) Work Unit with the main activities in the form of KKP priority activities, community assistance, or supporting priority activities and community assistance; b) Not Echelon III, because the budget allocation and financial transactions that occur are relatively small; c) Not a Technical Services Unit / UPT, because the transaction is still simple. Based on these criteria, 43 Work Units were selected which can be seen in the following table

Table 1. List Of Sample Members

\begin{tabular}{|c|l|}
\hline No & \multicolumn{1}{|c|}{ WORK UNIT NAME } \\
\hline 1 & $\begin{array}{l}\text { Secretariat of the Directorate General of Capture } \\
\text { Fisheries }\end{array}$ \\
\hline 2 & Marine Research Center \\
\hline 3 & Fisheries Research Center \\
\hline 4 & Bureau of Human Resources Apparatus \\
\hline 5 & Center for Marine and Fisheries Education \\
\hline 6 & Center for Quality Control \\
\hline 7 & Center for System and Compliance Standardization \\
\hline 8 & $\begin{array}{l}\text { Fish Quarantine Agency Secretariat, M Utu Control } \\
\text { and Fishery Product Safety }\end{array}$ \\
\hline 9 & $\begin{array}{l}\text { Secretariat of the Directorate General of Marine } \\
\text { and Fisheries Resources Supervision }\end{array}$ \\
\hline 10 & Directorate of Fisheries Resource Management \\
\hline 11 & Directorate of Marine Resources Management \\
\hline 12 & Directorate of Fleet Monitoring and Operations \\
\hline 13 & Directorate of Violation Handling \\
\hline 14 & $\begin{array}{l}\text { Bureau of Public Relations and Foreign } \\
\text { Cooperation }\end{array}$ \\
\hline 15 & KKP Secretariat General Planning Bureau \\
\hline 16 & $\begin{array}{l}\text { KKP General Secretariat Finance Bureau } \\
\text { Secretariat }\end{array}$ \\
\hline 18 & $\begin{array}{l}\text { Directorate of Fisheries Port Directorate General of } \\
\text { Capture Fisheries }\end{array}$ \\
\hline 17 and Organization General \\
\hline 12
\end{tabular}

\begin{tabular}{|c|c|}
\hline No & WORK UNIT NAME \\
\hline 19 & $\begin{array}{l}\text { Directorate of Fishing Vessels and Fishing } \\
\text { Equipment Directorate General of Capture Fisheries }\end{array}$ \\
\hline 20 & $\begin{array}{l}\text { Directorate of Fish Resource Management, } \\
\text { Directorate General of Capture Fisheries }\end{array}$ \\
\hline 21 & Directorate of Licensing and Service \\
\hline 22 & Directorate of Fish Area and Health \\
\hline 23 & Directorate of Seedling \\
\hline 24 & $\begin{array}{l}\text { Directorate of Aquaculture Production and } \\
\text { Business }\end{array}$ \\
\hline 25 & Directorate of Fish Feed and Medicine \\
\hline 26 & Directorate of Processing and Quality Management \\
\hline 27 & Directorate of Business and Investment \\
\hline 28 & Marketing Directorate \\
\hline 29 & Directorate of Logistics \\
\hline 30 & Directorate of Sea Space Planning \\
\hline 31 & Directorate of Marine Biodiversity and Conservation \\
\hline 32 & Directorate of Coastal and Small Islands Utilization \\
\hline 33 & Directorate of Marine Services \\
\hline 34 & $\begin{array}{l}\text { Bureau of General and Procurement of Goods / } \\
\text { Services }\end{array}$ \\
\hline 35 & Inspectorate General \\
\hline 36 & $\begin{array}{l}\text { Secretariat of the Directorate General of } \\
\text { Strengthening Competitiveness of Marine and } \\
\text { Fishery Products }\end{array}$ \\
\hline 37 & $\begin{array}{l}\text { Secretariat of the Directorate General of Marine } \\
\text { Space Management }\end{array}$ \\
\hline 38 & $\begin{array}{l}\text { Marine and Fisheries Counseling and Training } \\
\text { Center }\end{array}$ \\
\hline 39 & Center for Data, Statistics and Information \\
\hline 40 & $\begin{array}{l}\text { Secretariat of Marine and Fisheries Research and } \\
\text { Human Resources Agency }\end{array}$ \\
\hline 41 & Director General of Aquaculture \\
\hline 42 & Fish Quarantine Center \\
\hline 43 & $\begin{array}{l}\text { Institute for Management of Marine and Fisheries } \\
\text { Capital Business }\end{array}$ \\
\hline
\end{tabular}

Respondents in this study are the accounting/reporting section of the Work Unit in the Ministry of Maritime Affairs and Fisheries. The stages of testing are carried out as follows: descriptive statistical analysis, validity and reliability test, evaluation of goodness of fit, and hypothesis testing. 


\section{RESULTS AND DISCUSSIONS}

\subsection{Descriptive Statistics Analysis}

Based on table 2 below, it is evident that the implementation of internal audit has an average value of 4.14 which is 3.81. This shows that the perception of the average work unit apparatus does not yet understand the function of the application of information sharing and coordination of activities with the entire work unit apparatus. While the highest dimension average value is the planning dimension of 4.37. This shows that the perception of the average work unit has well understood the function of planning in setting priorities for risk-based work.

Table 2. Variable Description of the Implementation of Internal Audit.

\begin{tabular}{|l|l|r|r|}
\hline No & Dimensions & $\begin{array}{r}\text { Average } \\
\text { Score }\end{array}$ & $\begin{array}{r}\text { Standard } \\
\text { Deviation }\end{array}$ \\
\hline 1. & Planning & 4,37 & 0.77 \\
\hline 2. & Communication and approval & 4,04 & 0.80 \\
\hline 3. & Resource & 4,05 & 0,66 \\
\hline 4. & Policies and Procedures & 4,26 & 0.81 \\
\hline 5. & Coordination & 3,81 & 0.72 \\
\hline 6 & Reporting & 4,16 & 0.70 \\
\hline 7 & Monitoring & 4,28 & 0.79 \\
\hline \multicolumn{2}{|l|}{ Total } & 28,96 & \\
\hline \multicolumn{2}{|l|}{ Average } & 4,14 & \\
\hline
\end{tabular}

Source: Processed Primary Data, 2019

The Internal Control System variable, consisting of 5 dimensions, has an average value of 4.21 each reaching above 4.00 , which means that each work unit apparatus understands well every element in the internal control system

Table 3. Variable Description Of The Internal Control System.

\begin{tabular}{|r|l|r|r|}
\hline No & \multicolumn{1}{|c|}{ Dimensions } & $\begin{array}{r}\text { Average } \\
\text { Score }\end{array}$ & $\begin{array}{r}\text { Standard } \\
\text { Deviation }\end{array}$ \\
\hline 1. & Control Environment & 4,24 & 0,71 \\
\hline 2. & Risk Assessment & 4,14 & 0,67 \\
\hline 3. & Control Activities & 4,19 & 0,70 \\
\hline 4. & $\begin{array}{l}\text { Information and } \\
\text { Communication Systems }\end{array}$ & 4,25 & 0,75 \\
\hline 5. & Internal Control Monitoring & 4,25 & 0,71 \\
\hline \multicolumn{2}{|c|}{ Total } & 21,06 & \\
\hline \multicolumn{2}{|c|}{ Average } & 4,21 & \\
\hline
\end{tabular}

Source: Processed Primary Data, 2019

The following is a description of the variable quality of Financial Reports with 4 dimensions that are reflective
Table 4. Variable Description of the Financial Statement Quality:

\begin{tabular}{|c|c|c|c|}
\hline No & Dimensions & $\begin{array}{c}\text { Average } \\
\text { Score }\end{array}$ & $\begin{array}{l}\text { Standard } \\
\text { Deviation }\end{array}$ \\
\hline 1. & Relevance & 4,34 & 0.83 \\
\hline 2. & Reliable & 4,30 & 0.77 \\
\hline 3. & Comparability & 4,33 & 0,83 \\
\hline 4. & Understandability & 4,28 & 0.82 \\
\hline & Total & 17,24 & \\
\hline & Average & 4,31 & \\
\hline
\end{tabular}

The table data above explains the quality of financial statements has an average value of 4.31 where the value for each dimension reaches above 4.00, this means that on average each apparatus of the work unit understands the elements in the quality of financial statements consisting of relevance, reliability, comparability and understanding.

\subsection{Test Result of Validity and Reliability}

The following are the results of the factor loading construct of the Influence of Internal Audit Implementation on the Quality of Financial Reports Moderated The Effectiveness of the Internal Control System on Smart PLS:

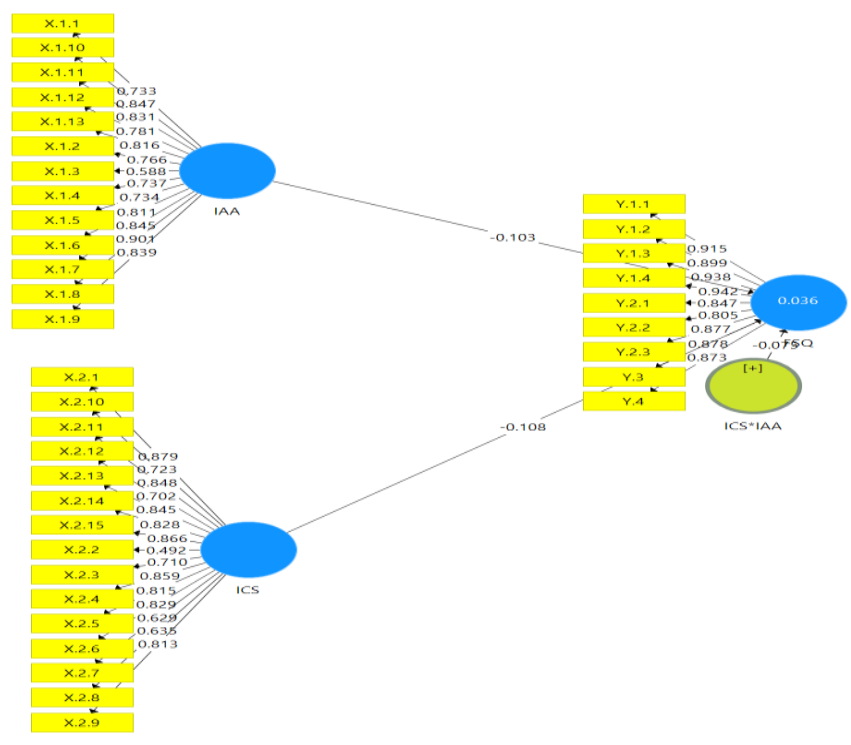

Figure 2 Research Variable Path \& Loading Factor Diagram

Based on the output on the path diagram above, the loading factor meets convergent validity, i.e. value of all the indicator value is above 0.5 at the significant level $5 \%$.

The reliability test results can be seen in the table below: 
Table 5. Reliability Test

\begin{tabular}{|c|c|c|c|c|}
\hline $\begin{array}{c}\text { Variable \& Dimensions } \\
\text { Implementation of Internal } \\
\text { Audit (X1) }\end{array}$ & 0.625 & 0.952 & 0.955 & Reliable \\
\hline $\begin{array}{c}\text { Effectiveness of the Internal } \\
\text { Control System (X2). } \\
\text { Moderating }\end{array}$ & 0.597 & 0.960 & 0.956 & Reliable \\
\hline $\begin{array}{c}\text { Quality of Financial } \\
\text { Statements (Y) }\end{array}$ & 0.597 & 0.968 & 0.971 & Reliable \\
\hline ICS*IAA & 1.000 & 1.000 & 1.000 & \\
\hline
\end{tabular}

Source: Processed Primary Data, 2019

The results of reliability output above, prove the variable of internal audit implementation, the effectiveness of internal control systems, and the quality of financial statements having Cronbach's Alpha above 0.6 and Composite Reliability above 0.7 , this means that the indicators used in each dimension have reliability that is good enough or able to measure the construct.

\subsection{Evaluate the Goodness of Fit Structural Model (Inner Model)}

Table 6. R-Square

\begin{tabular}{|c|c|c|}
\hline Variable & R Square & $\begin{array}{c}\text { R } \\
\text { Square } \\
\text { Adjusted }\end{array}$ \\
\hline Quality of Financial Statements $(Y)$ & 0,794 & 0,971 \\
\hline
\end{tabular}

Source: Processed Primary Data, 2019

The value of $\mathrm{R} 2$ for the financial report quality variable is 0.794 , which means that the financial report quality variable is explained by the internal audit implementation variable and the effectiveness of the internal control system $79.4 \%$, the remaining $21.6 \%$ is influenced by other variables not in the research model.

\subsection{Hypothesis Testing}

The following is a path diagram image for hypothesis testing:

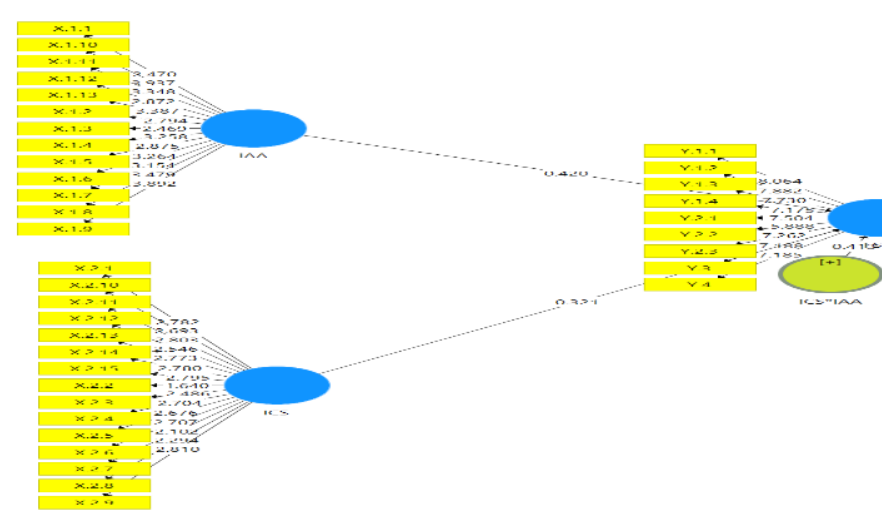

Figure 3 Path Diagram of the Hypothesis Testing
The path diagram of testing the hypothesis above, all dimensions in each variable have a T-statistic value greater than 1,660 so that these dimensions are able to measure each construct.

The path parameter coefficient obtained from the influence of the internal audit implementation variable on the financial report quality variable is -0.103 with a T-statistic value of $0.420<1.66$, there is no influence on the implementation of internal audit on the quality of financial statements. The path parameter coefficient obtained from the influence of the internal audit implementation variable on the quality of financial statements moderated the effectiveness of the internal control system is -0.075 with a T-statistic value $0.415<1.66$ states that the effectiveness of the internal control system moderates the influence of internal audit on the quality of financial statements.

Hypothesis test results stated that the implementation of internal audit does not affect the quality of financial statements. This means that the implementation of internal audits that have been carried out does not mean that they are not in line with internal control but rather complement each other. Although in reality the results of the 2016 and 2017 BPK-RI obtained a disclaimer opinion (not giving an opinion, this is partly due to differences in perceptions regarding the completeness of the evidence and accounting records in financial reporting. The role of internal audit does not support the quality of financial statements [10], The role of internal audit has no significant effect on the quality of local government financial reports [11], meaning that the role of financial supervisors does not significantly improve the quality of local government financial reports, while research that does not support the internal audit function has a positive effect on financial reporting quality and has implications for government governance [12]. The effectiveness of internal controls and the role of internal audit both partially and simultaneously affect government performance is better, as well as the variable effectiveness of internal control and the role of direct and indirect internal audit also affect the performance of local government [13]. The results of the hypothesis test also prove that the effectiveness of the internal control system does not moderate the influence of the implementation of internal audits on the quality of financial statements. This means that the implementation of internal audit does not affect the 
quality of financial statements, although moderated by the effectiveness of the internal control system still has no effect.

\section{CONCLUSION}

The implementation of internal audit does not affect the quality of financial statements. This means that the implementation of internal audit does not directly affect the quality of financial statements, because the internal audit does not assess the quality of financial statements. The effectiveness of the internal control system does not moderate the effect of the implementation of internal audit on the quality of financial statements.

The Work Unit in the Ministry of Maritime Affairs and Fisheries should continue to improve the capacity of human resources by including effective training. Improve discipline in implementing the Internal Control System and respond more quickly to the improvement of the findings of the internal supervisor team in this case the regional supervisors, thus the Quality of Financial Statements will increase.

\section{ACKNOWLEDGMENT}

This research is a Research Grant from the Directorate General of Higher Education which is included in the Master Thesis Research scheme. Therefore, we would like to express our deepest gratitude to the Directorate of Research and Community Service at the Directorate General of Higher Education for funding this research. Thank you also to the Universitas Mercu Buana Research Center for facilitating the conduct of this research. Likewise, those who have assisted in carrying out this research cannot be mentioned individually.

\section{REFERENCES}

[1] A. Suherman, Pengaruh Audit Internal Terhadap Kualitas Pelaporan Keuangan, Jurnal Pendidikan Akuntansi Dan Keuangan, Indonesia: Universitas Galuh, vol. 6(2), 2018, pp. 87-92.

[2] L. B. Sawyer, Internal Auditing, USA: The Internal Audit Foundation, $7^{\text {th }}$ ed, 2014.

[3] E. Erfiansyah, I. Kurnia, Peranan Auditor Internal Terhadap Kualitas Pelaporan Keuangan (Survei Pada Bank Perkreditan Rakyat di Kota Bandung, Kabupaten
BANDUNG, dan Kabupaten Bandung Barat), Jurnal Ilmiah Manajemen Ekonomi dan Akuntansi, Bandung: STIEM Bandung, vol. 2(2), vol. 3(1), 2018.

[4] T. Herawati, Pengaruh Sistem Pengendalian Intern Terhadap Kualitas Laporan Keuangan STAR - Study \& Accounting Research, STIE: STEMBI, 9 (1) 2014.

[5] Pemerintah RI, Pernyataan Standar Akuntansi Pemerintah (PSAP) Nomor 01, Penyajian Laporan Keuangan.

[6] A. Syarifudin, Pengaruh Kompetensi SDM dan Peran Audit Intern terhadap Kualitas Laporan Keuangan Pemerintah Daerah dengan Variabel Intervening Sistem Pengendalian Internal Pemerintah, Jurnal Fokus Bisnis, Kebumen: STIE Putra Bangsa, vol. 14 (02), 2014.

[7] H. Setiyawati, The effect of Internal Accountants' Competence, Managers' Commitment to Organizations and the Implementation of the Internal Control System on the Quality of Financial Reporting. International Journal of Business and Management Invention, Indonesia: IJBMI, vol. 2(11), 2013.

[8] Peraturan BPK RI No. 01, SPKN (Standar Pemeriksaan Keuangan Negara), 2017.

[9] D.R.Rahmatika, The Impact of Intern Audit Function effectiveness on Quality of Financial Reporting and its Implications on Good Government Governance Research on Local Government Indonesia, Research Journal of Finance and Accounting, Indonesia: IISTE, vol. 5 (18), 2014.

[10] Ikatan Akuntan Indonesia. PSAK No. 1, Tentang Laporan Keuangan, edisi revisi, Penerbit Dewan Standar Akuntansi Keuangan: PT. Raja Grafindo, 2015.

[11] Susilawati, D. S. Riana, Standar Akuntansi Pemerintahan dan Sistem Pengendalian Intern sebagai anteseden Kualitas Laporan Keuangan Pemerintah Daerah, STAR - Study \& Accounting Research, Bandung: STEMBI Bandung School, vol. 9(1), 2014.

[12] D. A. Budiawan, B. S. Purnomo, Pengaruh Sistem Pengendalian Internal Dan Kekuatan Koersif Terhadap Kualitas Laporan Keuangan Pemerintah Daerah, Jurnal Riset Akuntansi dan Keuangan, Bandung: UPI, 2 (1), 2014, pp. 276-288.

[13] Pengelolaan Dan Tanggung Jawab Keuangan Negara, 2015. 